\title{
Lluest Wen: the near failure and subsequent repair of a Pennine type dam
}

John Ackers BSc(Eng), CEng, FICE

Technical Director, Black and Veatch Ltd; Inspecting Engineer for Lluest Wen reservoir in 2008

Rachel Pether MEng, CEng, FICE

Project Director, Black and Veatch Ltd; Supervising Engineer for Lluest Wen reservoir (corresponding author: petherr@bv.com)
Alan Warren BSc(Eng), DIC, MSc, CEng, FICE

Technical Director, Mott MacDonald; Inspecting Engineer for Lluest Wen reservoir in 2018

The embankment dam at Lluest Wen reservoir in South Wales was a classic example of a Pennine type dam, with a slender puddle clay core. The dam's troubled history of settlement and leakage, culminating in a near dam breach 2 days before Christmas 1969, highlights the vulnerability of earthfill dams to internal erosion adjacent to appurtenant structures. The incident was a factor in the passing of the Reservoirs Act 1975 through Parliament. Nearly $\mathbf{5 0}$ years after the emergency and the completion of significant remedial and improvement works to the dam, it is appropriate to reflect on the causes of the incident and the performance of the works completed in the 1970 s.

\section{Introduction}

Lluest Wen reservoir is an impounding reservoir, retained by an embankment dam located across the headwaters of Afon Rhondda Fach upstream of Maerdy in South Wales (Figure 1). The dam comprises of an earthfill embankment with an original puddle clay core that was reinforced by a $600 \mathrm{~mm}$ thick plastic concrete diaphragm wall as part of remedial works in 1971-1973. This extends between 1 and $4 \mathrm{~m}$ into the underlying bedrock. There is also a short concrete cutoff wall in line with the dam axis, extending from its intersection with the plastic concrete wall at about the centre of the spillway channel into the left abutment (Figure 2).

The dam had a troubled history from the outset, suffering from settlement and leakage issues over the first 20 years after construction. This was followed in Christmas 1969 by a near failure of the dam, which led to an emergency drawdown of the reservoir, and subsequent major remedial and improvement works (Figure 3).

\section{Early history of the dam (1898-1917)}

The summary below of the early history of the dam, is mainly taken from the report of the 2008 Section 10 inspection of the reservoir by John Ackers, which drew on a paper by AC Twort (1977).

The reservoir was completed in about 1898 and, according to the historical records, there were repeated incidents of settlement and leakage over the first 20 years after construction. The first of these was a small settlement on the inner slope near the valve tower in 1903, which was 'made good'. In April 1908, water was seen flowing in the long rushes, and there was a considerable deposit of puddle on and among the rushes. Soon afterwards the top of the core was exposed, and found to be only 8 in above the top water level; however, no works to raise the core were carried out at this time.

In December 1910, a funnel-shaped hole appeared and was filled with about 40 barrow-loads of loose rubble. This recurred in January 1911 and was again filled. In December 1911, a hole $6 \mathrm{ft}(1.8 \mathrm{~m})$ long by $4 \mathrm{ft}(1.2 \mathrm{~m})$ wide and $3 \mathrm{ft}(0.9 \mathrm{~m})$ deep formed, with vertical sides, located between the puddle core and the top of the pitching. Subsequent to this, by early 1912 , the top of the core had been exposed at 13 points along the dam crest at $50 \mathrm{ft}$ intervals. It was concluded that the top of the core had originally been built to just $2 \mathrm{ft}$ $(0.6 \mathrm{~m})$ above top water level, that the maximum settlement since then had been 22 in $(560 \mathrm{~mm})$ and that there was evidence of some previous core raising near the south (right) end of the dam.

Settlement issues continued until 1917, and as a result of this, grouting repairs were undertaken from 1915 to 1917. It appears that there was divided opinion concerning the effectiveness of this grouting, and as a result various remedial options were proposed, including a new corewall, suggesting that the grouting had indeed not cured the problems with leakage. As well as problems with the puddle core and proposals for remedial measures, including replacing a section of the core with concrete, there are drawings from the time showing a proposal for a 'new discharge tunnel', passing around the left abutment, outside the line of the spillway. This would have been located around $8 \mathrm{~m}$ below the overflow level. The fact that this proposal was made suggests that there were problems with the original drawoff works and that consideration was presumably being given to decommissioning them.

In April 1917, a local government board inspector recommended that the reservoir should be emptied, or at least that 
Lluest Wen: the near failure and subsequent repair of a Pennine type dam

Ackers, Pether and Warren

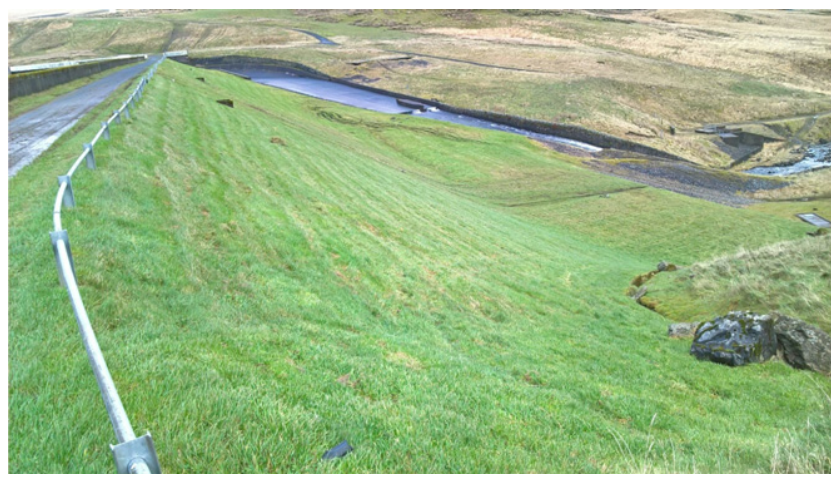

Figure 1. Downstream face of the dam and spillway, December 2017

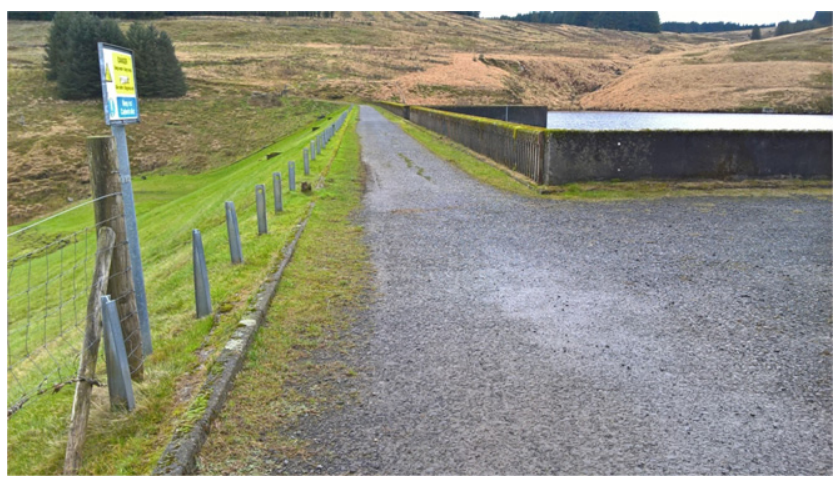

Figure 2. Crest and wavewall of the dam, December 2017

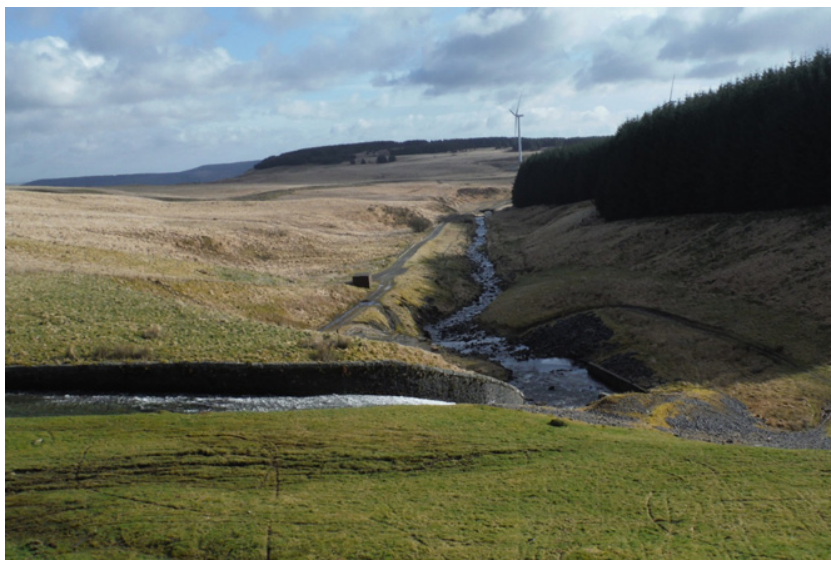

Figure 3. View looking downstream of the dam towards Maerdy. The access to the site proved challenging at the time of the 1969 incident the water level should be lowered and not allowed to rise sufficiently to endanger the stability of the dam. In September that year, the water board wrote to the local government board saying that it was satisfied that the works done to date had stopped the leakage and that 'all possibility of risk of failure of the embankment had been removed'. There is no evidence to suggest that any of the substantive measures shown on the drawings from the time were implemented.

Given the early history of the dam it is perhaps surprising that the following 50 year period of the dam's history was uneventful.

\section{Near failure of the dam (1969-1970)}

The events leading up to the major remedial measures in the 1970s are described by Twort (1977)

On 23rd December 1969 a hole, two metres deep was discovered in the crest of the dam, on the upstream side of the puddle clay corewall of the dam at a point close to the drawoff tower. The hole was discovered when a horse, being ridden along the crest of the dam, broke through the turf and gravel surface of the dam revealing a cavity below.

The dam was inspected on 1st and 7th January 1970. A $150 \mathrm{~mm}$ diameter drain pipe, to drain the base of the drawoff shaft, passing through the tunnel plug into the tunnel was found to be fractured within the tunnel plug. Water was seen entering this fracture and on testing proved to be clay bearing.

The inspections led to the conclusion on 9th January 1970 that the level of water in the reservoir must be reduced as a safety measure as quickly as possible.

An unexpected difficulty was that the bywash channel, which ran two thirds around the reservoir was found to be of little use for diverting catchment runoff, because it had suffered a reversal of gradient due to mining settlement. Upstream of the dam, its invert had settled at least $1 \mathrm{~m}$ due to coal mining outside the pillar of coal. (The dam itself had been protected from mining settlement due to a mining exclusion zone being placed around it.)

The primary work for lowering the water level therefore consisted of taking a cut through the spillway. Whilst this was proceeding, grouting of the dam in the vicinity of the drawoff tower was started on 19th January by the tube-à-manchette method using $32 \mathrm{~mm}$ diameter tubes. In four holes drilled either side of the tunnel plug, 45 tons of cement and bentonite were used in the sleeve grouting and 105 tons in the injection grouting.

By 29th January 1970 the cut had been taken down $9 \cdot 1 \mathrm{~m}$ (30 ft) below top water and a certificate for conditional safety of the dam was then issued. 
After the cessation of the emergency period at the end of January 1970, work continued on drilling and grouting the clay corewall across [the] dam at $3.0 \mathrm{~m}$ intervals. Into 61 holes a total of 300 tons of cement and 83 tons of bentonite was injected.

Site investigation drillings were also undertaken. The puddle core was found generally soft or very soft, consisting of sandy silty clay with pockets of silt or sand. Rock fragments and organic matter were scattered throughout. Piston samples revealed the core was cut by a series of cracks, many of which were open and iron stained by seepage water.

None of the grouting stemmed the original leakage into the $150 \mathrm{~mm}$ pipe through the tunnel plug.

By March 1970, a 33 in diameter pipe had been installed and concreted in the trench below the base of the emergency spillway cut and this pipe now forms a useful high-level drawoff. The emergency phase of the remedial works was completed in May 1970 and Mr Richard Phillips (of Binnie \& Partners) issued a certificate permitting use of the reservoir with a water level no higher than about $8 \mathrm{~m}$ below the present overflow level.

The efficient management of the incident was hampered by the poor access road provisions to the dam site. In discussing the incident management in the House of Commons, the secretary for Wales, Mr George Thomas stated

The first question which may be asked is whether the statutory provisions relating to the safety of reservoirs need to be strengthened. The responsible Departments, including my own, are already examining the existing statutory provisions with this purpose in mind. Last Friday, my Department wrote to all water undertakings with reservoirs in Wales asking them to make a special inspection of any reservoirs of similar construction, built before 1930, which they own, and to report within seven days. The letter called particular attention to the need to ensure that there is access to the dam capable of taking heavy vehicles and equipment if a critical condition developed. That is an important lesson of the Lluest Wen incident. (Hansard, 1970)

\section{Post failure remedial and improvement works (1971-1973)}

A decision was made that the dam should be fully restored and the design of the permanent remedial measures was put in hand. Work started in August 1971 and was substantially completed in March 1973, when a third preliminary certificate was issued, permitting impounding up to the present overflow level. The remedial works comprised the following

- Construction of a $600 \mathrm{~mm}$ thick plastic concrete diaphragm wall through the full length of the dam, taken through the puddle clay core and keyed into the bedrock.
- Grouting below the diaphragm.

- Installation of a new 27 in $(660 \mathrm{~mm})$ drawoff pipework replacing the previous 15 in pipework in the tunnel.

- Construction of an extension of the drawoff tower and conversion of the original wet tower to a dry tower configuration.

- Removal of the dam down to a level $0.5 \mathrm{~m}$ below top water level, and reconstruction of the dam crest above that level, including a substantial wavewall element sealed against the top of the diaphragm wall.

- Reconstruction and enlargement of the spillway headworks, including infilling the emergency cut below the spillway with rockfill and concrete.

- Adaptation of the temporary 33 in $(840 \mathrm{~mm})$ pipework installed beneath the spillway during the emergency phase of the remedial works, as a permanent high-level drawoff.

- Construction of a stilling basin for the drawoff/scour outlets.

- Construction of a rockfill berm at the downstream toe of the dam (Figure 4).

- Construction of a training wall at the downstream end of the spillway, with the placing of riprap protection.

- Improvements to the access road.

- Additional grouting in the valve tower area.

- Installation of piezometers.

- Installation of eight movement markers, on a line parallel to and $10 \mathrm{~m}$ downstream of the wavewall.

\section{Performance of the dam since the repairs (1975-2000)}

In the 1975 inspection report, Mr Phillips stated that mining had proceeded in two seams in the vicinity of the dam since 1970 and that 'Considerable settlement due to mining operations has occurred over the years except within the pillar beneath the dam.' Mining in the seams in the vicinity of the dam terminated in August 1976 and no further mining has been carried out since that time.

In 1999-2000, two new sources of apparent leakage were found, which formed the subject of a site investigation. The leakage was manifested at the following locations

(a) Through the base of the spillway sidewall, near the top of the part of the chute close to the left downstream mitre of the dam.

(b) At the left mitre of the embankment where it abuts onto solid ground.

Both leaks ceased when the reservoir level fell by about $1.8 \mathrm{~m}$ below the overflow level. It was concluded that the source of the leakage could be the original concrete corewall north of its junction with the new diaphragm wall beneath the new spillway structure, or the complex interface arrangements associated with the valve shaft and the 1971-1973 remedial 


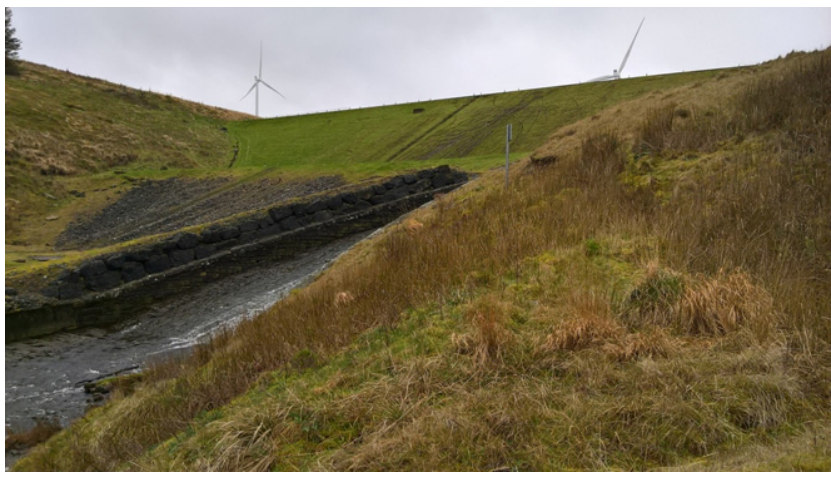

Figure 4. Rockfill berm constructed as part of the 1971-1973 works, December 2017

works. There was no evidence that the leakage was either progressive or causing any damage to the fabric of the dam and no further action, other than monitoring, was considered necessary.

\section{Current condition}

The reservoir is currently not utilised as the downstream reservoir of Castell Nos meets the current requirements for water supply. The substantial improvements in both spillway and drawdown capacity arising from the 1970s remedial works means that the reservoir meets the current stringent safety guidelines for flood safety and emergency drawdown provision. Seepage and deformation monitoring continue to be closely watched for any indications of progressive deterioration.

\section{Conclusions}

Lluest Wen is an example of an impounding reservoir, which was poorly designed and constructed and its history is marked by numerous remedial and improvement measures. The 1969 incident was of national significance and highlights the vulnerability of earthfill dams to internal erosion long after their construction, and the importance of good road access for emergency management. The subsequent passing of the Reservoirs Act 1975 introduced statutory supervision of large raised reservoirs through the introduction of supervising panel engineers. The authors speculate that such provisions might have prevented the 1969 incident had they been already in place.

\section{REFERENCES}

Hansard (1970) http:/hansard.millbanksystems.com/commons/1970/jan/ 19/wales-lluest-wen-reservoir (accessed 22/05/2018).

Twort AC (1977) The repair of Lluest Wen dam. Journal of the

Institution of Water Engineers and Scientists 31(4): 269-279.

\section{How can you contribute?}

To discuss this paper, please email up to 500 words to the editor at editor@britishdams.org. Your contribution will be forwarded to the author(s) for a reply and, if considered appropriate by the editorial board, it will be published as discussion in a future issue of the journal. 